\title{
The Influence of Size Firm and Ownership Structure TowardAggressive Tax Avoidance of Manufactur Companies Listed in Indonesia Stock Exchange
}

\author{
Ani Kusbandiyah \\ Universitas Muhammadiyah Purwokerto Indonesia \\ ami.kusbandiyah@yahoo.com
}

\author{
Norlia Mat Norwani \\ University Pendidikan Sultan Idris of Malaysia \\ norlia@fpe.upsi.edu.my
}

\begin{abstract}
This research aims to test the influence of size companies and the structure of ownership toward aggressive tax avoidance in consumer goods companies were listed on the Indonesia stock exchange period 2010-2014. The research methods used purposive sampling, in company of consumer goods the period 2010-2014, and analysis methods used multiple linear regression with significant levels of $(\alpha) 5 \%$. The results of study indicate the size companies and the family ownership has no negatively influence toward aggressive tax avoidance. While foreign ownership positively influence toward aggressive tax avoidance
\end{abstract}

Keywords: Aggressive Tax Avoidance, size companies, foreign ownership, family ownership

\section{INTRODUCTION}

Taxes are a source of revenue for the country, while the tax for companies is a burden that will reduce net profit, because of the amount of tax that is paid the company relatively small, then arose the indication that the company tend to do aggressive tax avoidance to create a tax paid becomes smaller. Although not all actions who do break the rules, but the more the gap used the company, then the company was considered the more aggressive tax action. It is therefore a tax avoidance aggresive activity includes legal tax planning activities or approaches the grey area, as well as illegal activities (Utamidan Setyawan,2015

Company size is an average net sales for the year in question until a couple of years measured using ln total assets. The company's maturity stage is determined based on total assets, the greater the total assets shows the company has good prospects in a relatively long period of time. Research prior by the Puspita dan Harto (2014) stated that the size of the company do not affect significantly to tax avoidance. However research sari (2014) stated that the size of the company has a significant influence of negative toward tax avoidance. (Richardson dan Lanis,2007) show a negative relationship with action company size to minimize taxes. Swingly dan Sukartha (2015) shpw that the total asset size of proxy which is the company's positive effect on tax avoidance. Ownership structure is an institution which has the benefit of investments including shares investment (Sari 2014).

The size firm measured using Ln total assets. Companies that have a low tax burden rate indicated has been doing aggressivetax avoidance. The company's size will effect a negative meaning the larger company will be getting lower (effective tax rate), ETR This is because the big companies are better able to use its own resources to make a good tax planning. Research conducted Sari (2014) stated that the size firm is measured by using the log total assets have significant influence negatively to tax avoidance. (Richardson and Lanis, 2007 stating a negative relationship with action size firm to minimize taxes.

Foreign ownership is the proportion of the company's shares are owned by individuals, legal entities, the Government as well as its parts are out of the country. The company and the shareholders prefer pay a smaller amount of tax and the use tax strategies that aggressive, Bradshaw et al (2014) Most of the company's ownership structure is concentrated on foreigners also tend to be doing tax avoidance. Companies are concentrated ownership, the phenomenon is happening in Indonesia is quite interesting where this phenomenon is different from the results of research (Chen et.al (2010), Zhang (2012) maupun Badertsher et.al (2013). Research by Desai et al. (2005) found that the United States multinational companies in the State income tax $10 \%$ higher then the physical investment will decrease of $6,6 \%$ (It means aggressive rate will lower taxes).

Setyawan (2015) cost arising from significant tax amount for all types of companies. Most of the company's ownership structure is concentrated on the family tend to do tax avoidance. (Prakosa, 2014) shows research results ownership families negatively to tax avoidance (tax avoidance).

This important research is done in order to be used as guidelines for companies listed on the Indonesia stock exchange to shrink the number of tax does not violate the rules of the applicable law and to create a policy or regulation regarding the action of aggressive tax avoidance. 


\section{METHOD}

The object of the research is the sector of consumer goods manufacturing company that is listed on Indonesia stock exchange period 2010-2014.

Method of data collection is done through secondary data collection is obtained from the website www.idx.co.id and www.google.com, the form data of the financial statements on company manufactures consumption good sector listed in Indonesia stock exchange period 2010-2014.

Populations and Samples

The population of research is the overall manufacturing companies listed on the Indonesia stock exchange period of 2010-2014. The sample in this study is sector of consumer goods manufacturing company that was taken using a purposive sampling techniques with the goal of keeping the representative sample obtained in accordance with specified criteria.

1. A consistent manufacturing companies listed on the Indonesia stock exchange belong to the sector of consumer goods the period $2010-2014$.

2. The company suffered no losses during years of research..

3. The company that owns ETR between 0-1, the lower value of the ETR (close to 0 ) then the company is considered the more aggressive taxes

Methods of data analysis used in this study is the analysis of multiple regression. In regression analysis, in addition to measuring the strength of a relationship between two or more variables, this analysis also indicates the direction of the relationship between the dependent variable independent variable. The equations of the regression models were used to test the hypothesis of the research are as follows:

$$
\mathrm{ATA}=\alpha+\beta 1 \mathrm{SIZE}+\beta 2 \mathrm{FAM}+\beta 3 \mathrm{FORG}+\mathrm{e}
$$

\section{RESULTS}

Selection process the samples in this study was consumer goods sector manufacturing companies listed on the Indonesia stock exchange (idx) during the research period 2010-2014, Company sector of consumer goods amounted to 37 companies, Researchers did not find the sectors of consumer goods manufacturing company that presents at annual financial reports that ends on December 31 , is two companies. The company does not have a structure foreign ownership and a structure family ownership is 23. Sample data that has the completeness of the data period 2010-2014 there are 60 data. Sample data is not lost during the period of 2010 2014 as much as 44 data, so the amount of data analysis that according the criteria as much as 44 data analysis.

The following multiple linear regression equation can be formulated in this research are as follows

$$
\mathrm{ATA}=0,272+0,000 \mathrm{UP}+0,001 \mathrm{KA}+0,000 \mathrm{KK}+\mathrm{e}
$$

\begin{tabular}{|c|c|r|c|c|c|}
\hline \multirow{2}{*}{ Model } & \multicolumn{2}{|c|}{$\begin{array}{c}\text { nstandardized } \\
\text { Coefficients }\end{array}$} & $\begin{array}{c}\text { Standardized } \\
\text { Coefficients }\end{array}$ & $\mathrm{t}$ & Sig. \\
\cline { 2 - 6 } & \multicolumn{1}{c|}{$\mathrm{B}$} & Std. Error & Beta & & \\
\hline (Constant) & .272 & .207 & & 1.314 & .196 \\
UP & .000 & .007 & -.016 & -.113 & .911 \\
KA & .001 & .000 & .417 & 2.764 & .009 \\
KK & .000 & .001 & -.049 & -.328 & .745 \\
\hline
\end{tabular}

\section{Coefficient of Determination}

From the results of the determination coefficient (R2) can be seen that the value adjusted $\mathrm{R}$ square of 0.130 or $13 \%$. This indicates that the power between of dependent variables (aggressive tax avoidance) with the independent variable i.e. size firm, foreign ownership and familly ownership of $13 \%$, and the rest of $87 \%$ is explained by other variables.

\section{ANOVA}

\begin{tabular}{|c|c|c|c|c|c|}
\hline Model & $\begin{array}{c}\text { Sum of } \\
\text { Squares }\end{array}$ & Df & $\begin{array}{c}\text { Mean } \\
\text { Square }\end{array}$ & F & Sig. \\
\hline 1 Regression & .059 & 3 & .020 & 3.141 & $\begin{array}{c}.036 \\
\mathrm{a}\end{array}$ \\
Residual & .252 & 40 & .006 & & \\
Total & .312 & 43 & & & \\
\hline
\end{tabular}

a. Predictors: (Constant), KK, UP, KA

b. Dependent Variable: ATA

From the table above, it can be noted that the value of significance was of 0.036 . The value of such significance $0.05<$ which means that $\mathrm{H}_{0}$ rejected. So, it can be concluded that the variable size of the companies, foreign ownership, and ownership of the family simultaneously influence toward aggressive tax avoidance.

\section{t-test}

Judging from the results of statistical tests $t$ above, be aware that there is one variable that the value of significance below 0.05 , namely foreign ownership variable. This shows that foreign ownership has significantly influence toward aggressive tax avoidance. Where as, the variable size of the company and the family ownership has no significantly influence toward aggressive tax avoidance. It is obtained because the value of significance which indicates its value more than 0.05 .

\section{Hypothesis Test}

Variable size of company shows the value significance $0.911>0.05$ that means there is no significant influence between the size of the company with aggressive tax avoidance, or $\mathrm{t}$ - value is -0.113 . While $t$ tabel is $-1,6629$. This means $-0.113>-1.6629$ and it can be concluded that the size of the company have not negatively influence toward aggressive tax avoidance, While the first hypothesis which States that the size of 
the company negatively influence toward aggressive tax avoidance was rejected.

The research is in line with studies Rego (2003), which stated that the company's size has no effect with tax avoidance. This means that the behavior of Aggressive Tax Avoidance phenomenon has not only done a great company, but chances are small or mediumscale companies is also the same, but not too have an impact on the revenue of the State. di Indonesia. In addition still weak surveillance business perpetrators fiskus parties, especially small-company Aggressive behavior thus causing the Tax Avoidance is spreading in all sizes of companies both small and large.

But the results of this research in contrast to research the sari (2014) stated that the size of the company has a significant influence of negative against tax avoidance and Swingly and Sukartha (2015) mention that total assets which is the proxy of the size of the company's positive effect on tax avoidance.

Foreign ownership variable shows the value significance $0,009<0,05$ that means there is a significant influence among foreign ownership with aggressive tax avoidance or $t$ value is 2,764 While t table is 1,6629 . This means 2,764 $>1,6629$ and it can be concluded that foreign ownership variable positive influence toward aggressive tax avoidance, so the second hypothesis States that foreign ownership have negatively on fluence toward aggressive tax avoidance was rejected.

This research supports research (Belinda, 2011) stating that foreign ownership had a positive influence in the tax avoidance. But in contrast to the research Alstadsaeter and Jacob (2013) found that tax incentives are used as a loophole for committing a tax avoidance and tax evasion (Nuritomo and Martani, 2014). But in contrast to the research Alstadsaeter and Jacob (2013) found that tax incentives are used as a loophole for committing a tax avoidance and tax evasion also (Nuritomo and Martani, 2014). This means that the higher foreign ownership will be increasingly highforeign companies doing practice aggressive tax avoidance because in accordance with the interests of companies that avoid paying taxes was featured on a company. But contrary to the tax payments that optimizes fiskus.

Family ownership variables shows the values of significance $0,745>0,05$ which means there is no significant influence among family ownership with aggressive tax avoidance or nilait ${ }_{\text {hitung }}$ sebesar $-0,328$ while $\mathrm{t}$ tabelsebesar $-1,6629$. This means $-0,328>-$ 1,6629 and it can be inferred that the family ownership have not negatively influence toward aggressive tax avoidance variables, so the third hypothesis which States that family ownership have negatively influence toward aggressive tax avoidance was rejected.

This research line Sari and Martani (2010) that the ownership of the family tend to relate positively with aggressive tax planning and contrary research Prakosa (2014) shows the results of the research of influential family ownership negative against tax avoidance. The results of the study stated that the ownership of the family do not affect negatively to aggressive tax avoidance because of the amount of family ownership in the manufacturing sectors of consumer goods companies is very small so it could not affect the practices of aggressive tax avoidance. A company listing in the Indonesia stock exchange (IDX) usually have a small percentage of family ownership.

\section{CONCLUTION}

The first hypothesis was rejected. The size of the company do not affect negatively to aggressive tax avoidance. The second hypothesis was rejected. Foreign ownership effect positively to aggressive tax avoidance The third hypothesis was rejected. Family ownership has no effect negatively to aggressive tax avoidance.

Further research is recommended to increase the span of years of research in order to see more clearly the behavior of companies associated with aggressive tax avoidance activities, expand sample research as service companies, banks, automotive and more, as well as adding other variables associated aggressive tax avoidance. For the Government, it is expected that further enhance the surveillance or fiskus monitoring against firms that reported tax obligation Especially companies that reported losses in two consecutive years, because it was feared the company reported a loss can take advantage of the loophole such as utilizing a fiscal loss compensation to reduce tax burden companies in next period.

\section{REFERENCES}

[1] Chen, S., Chen, X., \& Cheng, Q.Are Family Firms more Tax Aggressive than Non- family Firms? Journal of Financial Economics, 95(1), 41-61.2010.

[2] Chen, Z., Cheok, C. K., \& Rasiah, R. Corporate Tax Avoidance and Performance: Evidence from China's Listed Companies. Institutions and Economies, 8(3), 61-83.2016

[3] Hidayanti, A. N., \& Laksito, H. Pengaruh antara Kepemilikan Keluarga dan Corporate Governance terhadap Tindakan Pajak Agresif. Journal of Accounting, 2, 1-12. 2013

[4] Puspita, S. R., \& Harto, P. Pengaruh Tata Kelola Perusahaan Terhadap Penghindaran Pajak. Diponegoro Journal Of Accounting. 2014

[5] Richardson, G., \& Lanis, R. (2007). Determinants of the variability in corporate effective tax rates and tax reform: Evidence from Australia. Journal of Accounting and Public Policy, 26(6), 689-704.

[6] Robinson, J., Xue, Y., \& Zhang, M. Tax planning and financial expertise in the audit committee. University of Texas at Austin, 1-40.2012

[7] Sari, G. M. Pengaruh Corporate Governance, Ukuran Perusahaan, Kompensasi Rugi Fiskal Dan 
Struktur Kepemilikan Terhadap Tax Avoidance. Jurnal WRA.2014

[8] Setyawan, W. T. U. dan H. Pengaruh Kepemilikan Keluarga terhadap Tindakan Pajak Agresif dengan Corporate Governance sebagai Variabel Moderating (Studi Empiris pada Perusahaan
Manufaktur yang Terdaftar Di Bursa Efek Indonesia Tahun 2010-2013. Public Choice. 2015

[9] Swingly, C., \& Sukartha, I. M. PengaruhKarakter Eksekutif, Komite Audit, Ukuran Perusahaan, Leverage, dan Sales Growth pada Tax Avoidance. E-Jurnal Akuntansi Universitas Udayana, 1, 4762.2015 